\title{
Chemical profiles and antimicrobial activities of plants utilized in Brazilian traditional medicine
}

\author{
Rafaela Souza Silva ${ }^{1}{ }^{\oplus}$, Marcílio Wagner Fontes da Silva ${ }^{1}{ }^{\oplus}$, Giselle Barbosa Bezerra ${ }^{1}$, Clécio \\ Souza $\operatorname{Ramos}^{1+}{ }^{+}$
}

1.Universidade Federal Rural de Pernambuco, Departamento de Química, Recife, Pernambuco, Brazil.

+Corresponding author: Clécio Souza Ramos, Phone: +55 81 3320-6379, Email address: clecio.ufrpe@gmail.com

\section{ARTICLE INFO}

Article history:

Received: September 05, 2019

Accepted: May 25, 2020

Published: January 01, 2021
Keywords

1. Antimicrobial activity

2. Anacardium occidentale

3. Handroanthus impetiginosus

4. Bumelia sartorum

5. Zornia brasiliensis

6. Cnidosculus urens

ABSTRACT: Medicinal plants are used for primary health care in many countries. In Brazil, there are hundreds of street markets selling a wide variety of herbs for medicinal purposes without quality control or scientific evidence; instead, their purported efficacy is based exclusively on empirical ethnobotanical knowledge. The present study evaluated the effectiveness of five medicinal plants widely utilized in Brazil to treat infections, as well as determined their chemical profiles. The results revealed that the five plants investigated (Anacardium occidentale L., Handroanthus impetiginosus Mart., Bumelia sartorum Sw., Zornia brasiliensis Vogel and Cnidosculus urens Pohl) demonstrated moderate to strong antimicrobial activity against most fungi and bacteria tested, principally for infections caused by gram-negative bacteria. The extracts of four plants exhibited MIC of $19.5 \mu \mathrm{g} \mathrm{mL} \mathrm{m}^{-1}$ against the bacterium Escherichia coli. The results also confirmed that these five traditional medicinal plants are efficient and inexpensive alternative sources of substances to treat infections. The samples of the commercially marketed plants did not have consistent chemical compositions in at least one type of HPLC, GC/MS, UV or ${ }^{1} \mathrm{H}$ NMR analysis.

\section{Samples of Handroanthus impetiginosu}

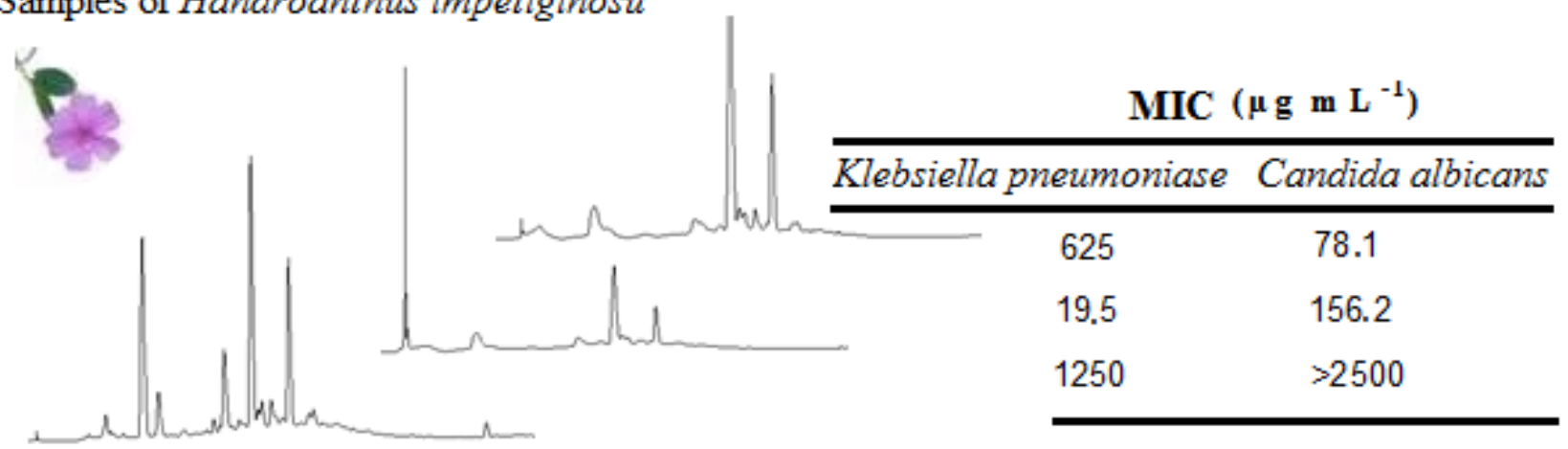

Chemical profile variation

Changes MIC values 


\section{Introduction}

Since the beginning of human civilization, plants have been utilized for a wide array of purposes ${ }^{1}$. It is estimated that around $80 \%$ of the global population relies on medicinal plants for primary health care ${ }^{1-3}$. It is also estimated that more than $65 \%$ of commercial pharmaceutical preparations contain active ingredients from natural sources, $32 \%$ being natural compounds or derivatives ${ }^{4}$. Over a period of 30 years (1981 to 2014), $43.5 \%$ of the medicines in the world approved for the treatment of infections caused by bacteria, fungi, parasites and viruses were obtained from natural products $^{5}$. Morphine, isolated from Papaver somniferum L., penicillin, obtained from fermentative processes of Penicillium chrysogenum Thom, and taxol, isolated from Taxus brevifolia Nutt., are among drugs developed from natural sources ${ }^{6}$. Despite the advantages of using medicinal plants, such as their lower cost, fewer side effects, greater protection and easier accessibility, there are still considerable risks to consumers due to problems of self-dosing, variability in the chemical standards and inflated marketing claims regarding herbs ${ }^{7}$.

Brazil has the largest biodiversity in the world and $50 \%$ of plant species of the family Leguminosae have been reportedly used in folk medicine ${ }^{8}$. Hence, it is not surprising that street markets flourish selling myriad species of herbal and plant cures for an array of common ailments. Moreover, $66 \%$ of the Brazilian population has no full access to commercial medicines ${ }^{9}$. Indeed, medical anthropologists have verified the existence of time-tested ethnobotanical knowledge among cultures worldwide ${ }^{10}$, including in Brazil $^{11,12}$. There is no doubt about the importance of medicinal plants for the treatment and prevention of diseases. As part of the systematic study of phytochemicals and biological activity, previously were demonstrated the antidiarrheal property of Solanum paniculatum, L. roots, used in Brazil for culinary purposes and to treat gastric dysfunctions ${ }^{13}$. However, a lack of information about the origin, taxonomic identification, storage and chemical standardization of plants is a potential drawback to their safe consumption, posing possible health risks to users, particularly those in poor health ${ }^{14}$. Hence, the present study aimed to determine the chemical profile and antimicrobial potential of five medicinal plants (Anacardium occidentale L., Handroanthus impetiginosus Mart., Bumelia sartorum Sw., Zornia brasiliensis Vogel and Cnidosculus urens Pohl) popularly used in Brazil for the treatment of infections.
A. occidentale, known in Brazil as purple cashew, used in the form of tea and juice, is indicated for treatment of infections via oral administration and for wound healing by topical application ${ }^{15,16}$. The stems and flowers of $H$. impetiginosus, known as purple Ipê, are used to make poultices or concentrated as tea for the treatment of diseases caused by microorganisms ${ }^{17-19}$. Stems of $B$. sartorum, known as quixaba, are used in Northeast Brazil to prepare for treatment of various conditions, such as diabetes mellitus, inflammation, genital sores, colic, bruises, ulcers and others ${ }^{20}$. Extracts of leaves of $Z$. brasiliensis, known as urinana, are used for their molluscicidal, spasmolytic, muscle relaxant and anticonvulsant properties and reportedly possess antioxidant, antibacterial, cytotoxic, antinociceptive, antiinflammatory and antitumor activities ${ }^{21}$. Extracts from roots of the white nettle, $C$. urens, are indicated for the treatment of cancer, inflammation, infection and dermatological lesions, besides being used for their antiseptic, expectorant, tonic, antispasmodic, diuretic, sedative and hemostatic activities ${ }^{22}$.

\section{Experimental}

\subsection{Plant material}

\subsubsection{Plant selection}

The plant species were selected based on professed traditional ethnobotanical knowledge. Ten suppliers selling herbs at the São José market in the city of Recife (the state capital of Pernambuco, population $1,645,727 ; 2020)$ were interviewed by researchers and asked to identify the medicinal plants most frequently purchased by their customers for treating common infectious diseases. Anacardium occidentale (stems), Handroanthus impetiginosus (stems), Bumelia sartorum (stems), Zornia brasiliensis (leaves) and Cnidosculus urens (roots) were the plant species most frequently indicated by the herb vendors and thus, were selected for the study. Samples of these five plant species were purchased from three different medicinal plant suppliers in March 2018.

\subsubsection{Obtaining extracts}

The five selected plants were dried at $50{ }^{\circ} \mathrm{C}$ for 48 h. The plants were milled and extracted separately with ethanol $(3 \times 100 \mathrm{~mL})$. The extract obtained was concentrated under reduced pressure at $45^{\circ} \mathrm{C}$ to yield the crude extract (Tab. 1). The extracts were subjected to chromatographic and spectrometric analysis (HPLC, GC/MS, UV-VIS e ${ }^{1} \mathrm{H}$ NMR). 
Table 1. Yields values of extracts obtained with ethanol from the five plants selected.

\begin{tabular}{|c|c|c|c|c|}
\hline \multicolumn{2}{|l|}{ Samples } & Dried plants (g) & Crude extracts (g) & Yielding (\%) \\
\hline \multirow{3}{*}{ A. occidentale } & $1 \mathrm{Ao}$ & 32.3 & 0.7 & 2.0 \\
\hline & $2 \mathrm{Ao}$ & 19.1 & 0.6 & 3.0 \\
\hline & 3Ao & 40.3 & 0.8 & 2.0 \\
\hline \multirow{3}{*}{ H. impetiginosus } & $1 \mathrm{Hi}$ & 43.4 & 1.0 & 2.2 \\
\hline & $2 \mathrm{Hi}$ & 32.2 & 2.1 & 6.7 \\
\hline & $3 \mathrm{Hi}$ & 26.7 & 1.4 & 5.3 \\
\hline \multirow{3}{*}{ B. sartorum } & $1 \mathrm{Ba}$ & 56.4 & 1.2 & 2.2 \\
\hline & $2 \mathrm{Ba}$ & 29.9 & 0.9 & 2.8 \\
\hline & $3 \mathrm{Ba}$ & 36.4 & 2.6 & 7.3 \\
\hline \multirow{3}{*}{ Zornia sp } & $1 \mathrm{Zs}$ & 18.9 & 0.5 & 2.7 \\
\hline & $2 \mathrm{Zs}$ & 17.3 & 0.5 & 3.2 \\
\hline & $3 \mathrm{Zs}$ & 23.5 & 0.65 & 2.7 \\
\hline \multirow{3}{*}{ C. urens } & $1 \mathrm{Cu}$ & 20.5 & 0.5 & 2.9 \\
\hline & $2 \mathrm{Cu}$ & 24.0 & 0.3 & 1.1 \\
\hline & $3 \mathrm{Cu}$ & 21.5 & 0.2 & 1.0 \\
\hline
\end{tabular}

\subsection{Instruments}

GC/MS analysis were carried out using a Perkin Elmer, model Clarus 589/Clarus SQ 8S capillary column (cross linked 5\% phenyl methyl silicone, 0.25 $\mathrm{mm}$ i.d. x $30 \mathrm{~m}$, Palo Alto, CA, USA), with oven temperature programmed from 100 to $250{ }^{\circ} \mathrm{C}$ at $10{ }^{\circ} \mathrm{C}$ $\min ^{-1}$ rate and a carrier gas (helium) flow rate of $1 \mathrm{~mL}$ $\min ^{-1}$. IR spectra were measured in $\mathrm{KBr}$ pellets with a Varian infrared spectrometer. The VIS-UV analyses were carried out in an Agilent 8453 UV-Vis spectrophotometer in the interval from 200 to $480 \mathrm{~nm}$, using $10-\mathrm{mm}$ quartz cuvettes. ${ }^{1} \mathrm{H}$ NMR analyses were recorded at $300 \mathrm{MHz}$ using a Varian Unity Plus equipment. Samples were dissolved in $\mathrm{CDCl}_{3}$ with TMS as the internal standard. HPLC analyses of extracts and pure compounds were performed in a Shimadzu LC 20AT instrument using a Luna $\mathrm{C}_{18}$ reverse phase column $(250 \times 4.6 \mathrm{~mm} \times 5 \mu \mathrm{m}$, Phenomenex) and eluted in gradient mode starting with $0.001 \%$ formic acid/methanol (3:7) for $5 \mathrm{~min}$, rising to $90 \%$ formic acid after $30 \mathrm{~min}$, with diode array detector. TLC was performed on pre-coated silica gel $60 \mathrm{~F}_{254}$ plates. Spots were visualized under UV light (254 and $365 \mathrm{~nm})$.

\subsection{In vitro assay for antimicrobial activity}

The antimicrobial assay with crude extracts of the five plants studied was evaluated against the grampositive bacteria Bacillus subtilis (UFPEDA 86), Enterococcus faecalis (UFPEDA 138), the grampositive bacteria Escherichia coli (UFPEDA 224) and Klebsiella pneumoniae (UFPEDA 396), as well as against the fungi Candida albicans (ATCC 1007) and Candida krusei (UFPEDA 1002). The microorganisms were maintained in nutrient agar (NA), stored at $4{ }^{\circ} \mathrm{C}$. The antimicrobial activity evaluation was performed by determination of the values of minimum inhibitory concentrations (MIC), as previously reported ${ }^{23}$.

\section{Results and discussion}

The chemical profiles of the ethanolic extracts of $A$. occidentale (stems), $H$. impetiginosus (stems), $B$. sartorum (stems), Z. brasiliensis (leaves) and C. urens (roots) marketed as medicinal plants in Recife, Pernambuco, Brazil and indicated for the treatment of common infectious diseases were obtained by HPLC, TLC, GC/MS, UV and ${ }^{1} \mathrm{H}$ NMR analysis. Based on the interpretations of the spectroscopic and chromatographic analyses (see Supplementary Material, Figures S1-S15), some plant samples showed qualitative and quantitative differences in the chemical profiles in at least one type of analysis. The chemical profiles of $B$. sartorum specimens had the greatest chemical similarity among the five plants analyzed. The ${ }^{1} \mathrm{H}$ NMR spectra of the ethanolic extracts of $B$. sartorum samples revealed signals from the region of 0.9 to $5.5 \mathrm{ppm}$ as bassic acid. Previous isolates from $B$. sartorum root bark and bassic acid have demonstrated anti-inflammatory activity ${ }^{24}$. Despite the small variation in the chemical profiles among the $B$. sartorum samples, the antimicrobial potential of $B$. sartorum showed a variation of MIC values, especially for sample 3Ba, which presented lower activity against the bacterium Escherichia coli and the fungus Candida albicans (Tab. 2). 
Table 2. Minimum inhibitory concentrations (MIC) values in $\mu \mathrm{g} \mathrm{mL}^{-1}$.

\begin{tabular}{|c|c|c|c|c|c|c|c|}
\hline \multirow{2}{*}{ Plants } & \multirow{2}{*}{ Samples } & \multicolumn{2}{|c|}{ Gram-positive bacteria } & \multicolumn{2}{|c|}{ Gram-negative bacteria } & \multicolumn{2}{|c|}{ Fungi } \\
\hline & & E. faecalis & B. subtilis & E. coli & K. pneumoniae & C. krusei & C. albicans \\
\hline \multirow{3}{*}{ A. occidentale } & $1 \mathrm{Ao}$ & 312.5 & 312.5 & 156.2 & 19.5 & 312.5 & 1250 \\
\hline & $2 \mathrm{Ao}$ & 156.2 & 78.1 & 78.1 & 19.5 & 625 & 2500 \\
\hline & 3Ao & 312.5 & 312.5 & 19.5 & 19.5 & 78.1 & 1250 \\
\hline \multirow{3}{*}{ H. impetiginosus } & $1 \mathrm{Hi}$ & 1250 & 625 & 19.5 & 1250 & 2500 & $>2500$ \\
\hline & $2 \mathrm{Hi}$ & 1250 & 625 & 156.2 & 625 & 2500 & 78.1 \\
\hline & $3 \mathrm{Hi}$ & 78.1 & 19.5 & 78.1 & 19.5 & 2500 & 156.2 \\
\hline \multirow{3}{*}{ B. sartorum } & $1 \mathrm{Ba}$ & 1250 & 625 & 19.5 & 625 & 39.0 & $>2500$ \\
\hline & $2 \mathrm{Ba}$ & 625 & 625 & 19.5 & 39.0 & 39.0 & 39.0 \\
\hline & $3 \mathrm{Ba}$ & 1250 & 625 & 1250 & 312.5 & $>2500$ & 625 \\
\hline \multirow{3}{*}{ Zornia sp } & $1 \mathrm{Zs}$ & 1250 & 1250 & 625 & 625 & $>2500$ & $>2500$ \\
\hline & $2 \mathrm{Zs}$ & 1250 & 625 & 625 & 625 & $>2500$ & 2500 \\
\hline & $3 Z s$ & 1250 & 312.5 & 625 & 625 & $>2500$ & 78.1 \\
\hline \multirow{3}{*}{ C. urens } & $1 \mathrm{Cu}$ & 1250 & 625 & 625 & 2500 & $>2500$ & $>2500$ \\
\hline & $2 \mathrm{Cu}$ & 1250 & 625 & 19.5 & 625 & 19.5 & 625 \\
\hline & $3 \mathrm{Cu}$ & 1250 & 625 & 19.5 & 625 & 19.5 & 625 \\
\hline
\end{tabular}

The chemical profile of $H$. impetiginosus sample 1Hi presented a difference when compared to the chemical profiles of samples $\mathbf{2} \mathbf{H i}$ and $\mathbf{3 H i}$, mainly in the HPLC and UV analyses. $H$. impetiginosus exhibited strong antimicrobial activity with MIC of $19.5 \mu \mathrm{g} \mathrm{mL}^{-1}$ against the bacteria E. coli, B. subtilis and $K$. pneumonia, but the MIC values varied among the samples due to their different chemical profiles.

The chemical profiles of ethanolic extracts of the $Z$. brasiliensis samples showed differences when analyzed by HPLC, UV and ${ }^{1} \mathrm{H}$ NMR, especially sample 2Zs. It was observed in the ${ }^{1} \mathrm{H}$ NMR spectrum of the $Z$. brasiliensis extract the presence of doublets at $\delta 7.6$ and $7.30 \mathrm{ppm}$, an intense singlet from the methoxy group at $\delta 3.9 \mathrm{ppm}$, while the UV spectrum showed absorption in the 380 to $560 \mathrm{~nm}$. These signals indicate the presence of flavonoids in the extract. Flavonoids as chalcones and flavones have been previously reported of $Z$. brasiliensis tissues, and flavone 7-methoxyflavone isolated from the aerial exhibited antinociceptive activity ${ }^{25}$. Among the species of plants studied here, Z. brasiliensis presented the least antimicrobial potential against all microorganisms tested.

The chromatograms obtained by HPLC of the three C. urens extract samples showed a major peak at $\mathrm{t}_{\mathrm{r}} 40$ min. The chemical profiles showed qualitative and quantitative differences, mainly the chromatogram of the $1 \mathrm{Cu}$ sample. It was inactive against the fungi $C$. albicans and C. krusei, as well as presenting weak activity against all bacteria tested. The samples $\mathbf{2 C u}$ and $\mathbf{3 C u}$, on the other hand, showed better results with strong activity against the gram-negative bacterium $K$. pneumoniae and the fungus $C$. krusei, with MIC of
$19.5 \mu \mathrm{g} \mathrm{mL}{ }^{-1}$. The ${ }^{1} \mathrm{H}$ NMR spectra of $C$. urens extracts did not indicate the presence of hydrogen signals for aromatic compounds but showed standard signals of triterpenoids between $\delta 5.0$ and $0.8 \mathrm{ppm}$, identical to the triterpenoid signals previously obtained for ethanolic extracts of $C$. urens $^{26}$.

Extracts from the A. occidentale samples exhibited strong antimicrobial activity against the bacteria tested, mainly against the gram-negative bacteria $K$. pneumonia and $E$. coli, corroborating previous studies which demonstrated the antimicrobial potential of $A$. occidentale $^{27,28}$. The ${ }^{1} \mathrm{H}$ NMR analysis of $A$. occidentale samples revealed chemical signals characteristic of flavonoids and benzoic acid derivatives, such as quercetin, kaempferol, rhamnetin and 2-hydroxy-6-pentadecylbenzoic acid, previously observed in extracts of $A$. occidentale tissues ${ }^{29,30}$.

\section{Conclusions}

In summary, the five medicinal plants popularly indicated for treating common infectious diseases in Recife, Brazil, showed moderate to strong antimicrobial activity against most of the fungi and bacteria tested, principally gram-negative bacteria, responsible for most infection-related deaths.

The results confirmed that these five traditional medicinal plants are efficient low-cost sources of extracts to treat infections, especially for the 5.1 million of Brazilians living in abject poverty ${ }^{31}$ who have limited access to conventional medicines, as well as for other people seeking natural cures. The study also revealed that samples of the commercially marketed plants failed to have a consistent chemical 
composition in at least one type of HPLC, GC/MS, UV or ${ }^{1} \mathrm{H}$ NMR analysis. Another drawback noted was the lack of information about the authenticity of herbs on the packaging. The samples' variability suggests a need for more rigorous quality control of informally marketed herbal medicines in this setting to avoid potential risks to consumers' health.

\section{Acknowledgments}

This work was funded by grants from PRPPG/UFRPE. RSS thanks CAPES for providing a scholarship. The authors are indebted to the Centro de Apoio a Pesquisa (CENAPESQ), UFRPE, for the laboratory facilities.

\section{References}

[1] Elekwa, I., Ugbogu, A. E., Okereke, S. C., Okezie., E., A Review of Selected Medicinal Plants with Potential Health Benefits in South-Eastern Nigeria, International Journal of Pharmaceutical and Chemical Sciences 6 (4) (2017) 162171 .

[2] Albuquerque, U. P., Hanazaki, N., As pesquisas etnodirigidas na descoberta de novos fármacos de interesse médico e farmacêutico: fragilidades e perspectivas, Revista Brasileira de Farmacognosia 16 (Suppl) (2006) 678-689. https://doi.org/10.1590/S0102-695X2006000500015.

[3] Pattanaik, C., Reddy, C. S., Medicinal Plant Wealth of Local Communities in Kuldiha Wildlife Sanctuary, Orissa, India, Journal of Herbs, Spices \& Medicinal Plants 14 (3-4) (2008)

$175-184$. https://doi.org/10.1080/10496470802598800.

[4] Newman, D. J., Cragg, G. M., Natural Products as Sources of New Drugs over the 30 Years from 1981 to 2010, Journal of Natural Products 75 (3) (2012) 311-335. https://doi.org/10.1021/np200906s.

[5] Newman, D. J.; Cragg, G. M., Natural Products as Sources of New Drugs from 1981 to 2014, Journal of Natural Products $79 \quad$ (3) (2016) 629-661. https://doi.org/10.1021/acs.jnatprod.5b01055.

[6] Barreiro, E. J., Fraga, C. A., M., Química Medicinal: As Bases Moleculares da Ação dos fármacos, Artmed, Porto Alegre 3rd ed., 2015.

[7] Yevale, R., Khan, N., Jagtap, P., Kale, M., A review on Herbal Medicine: Current Scenario, European Journal of Biomedical and Pharmaceutical Sciences 3 (4) (2016) 109120. https://storage.googleapis.com/journaluploads/ejbps/article_issue/volume_3_april_issue_4/145940 6264.pdf.
[8] Souza, E. N. F., Williamson, E. M., Hawkins, J. A., Which Plants Used in Ethnomedicine Are Characterized? Phylogenetic Patterns in Traditional Use Related to Research Effort, Frontiers in Plant Science 9 (2018) 834. https://doi.org/10.3389/fpls.2018.00834.

[9] Mazzari, A. L. D. A., Prieto, J. M., Herbal medicines in Brazil: pharmacokinetic profile and potential herb-drug interactions, Frontiers in Pharmacology 5 (2014) 162. https://doi.org/10.3389/fphar.2014.00162.

[10] Urso, V., Signorini, M. A., Tonini, M., Bruschi, P., Wild medicinal and food plants used by communities living in Mopane woodlands of southern Angola: Results of an ethnobotanical field investigation, Journal of $\begin{array}{llll}\text { Ethnopharmacology } & 177 \quad \text { (2016) } & 126-139 .\end{array}$ https://doi.org/10.1016/j.jep.2015.11.041.

[11] Conde, B. E., Ticktin, T., Fonseca, A. S., Macedo, A. L., Orsi, T. O., Chedier, L. M., Rodrigues, E., Pimenta, D. S., Local ecological knowledge and its relationship with biodiversity conservation among two Quilombola groups living in the Atlantic Rainforest, Brazil, PLoS One 12 (11) (2017) e0187599. https://doi.org/10.1371/journal.pone.0187599.

[12] Almeida, C. F. C. B. R., Albuquerque, U. P., Uso e conservação de plantas e animais medicinais no Estado de Pernambuco (Nordeste do Brasil): um estudo de caso, $\begin{array}{lllll}\text { Interciencia } & 27 & \text { (6) } & \text { (2002) }\end{array}$ https://www.redalyc.org/pdf/339/33906902.pdf.

[13] Tenório, J. A. B., Monte, D. S., da Silva T. M. G., Silva, T. G., Ramos, C. S., Solanum paniculatum root extract reduces diarrhea in rats, Revista Brasileira de Farmacognosia $26 \quad$ (3) 375-378. https://doi.org/10.1016/j.bjp.2016.02.003.

[14] Ghorani-Azam, A., Sepahi, S., Riahi-Zanjani, B., Ghamsari, A. A., Mohajeri, S. A., Balali-Mood, M., Plant toxins and acute medicinal plant poisoning in children: A systematic literature review, Journal of Research in Medical $\begin{array}{llll}\text { Sciences } & 23 & \text { (2018) }\end{array}$ https://www.jmsjournal.net/temp/JResMedSci231266450134_175501.pdf.

[15] Njinga, R. L., Jonah, S. A., Gomina, M., Preliminary investigation of naturally occurring radionuclides in some traditional medical plants used in Nigeria, Journal of Radiation Research and Applied Sciences 8 (2) (2015) 208215. https://doi.org/10.1016/j.jrras.2015.01.001.

[16] Olaniyan, M. F., Cholesterol Lowering Effect of Cashew Leaf (Anacardium occidentale) Extract on Egg Yolk Induced Hypercholesterolaemic Rabbits, Scholars Academic Journal of Biosciences 4 (10B) (2016) 886-891. https://www.edouniversity.edu.ng/oerrepository/articles/chol esterol_lowering_effect_of_cashew_leaf_anacardium_occid 
entale_extract_on_egg_yolk_induced_hypercholesterolaemi c_rabbits.pdf.

[17] Park, J. G., Yi, Y.-D., Han, S. Y., Hong, Y. H., Yoo, S., Kim, E., Jeong, S.-G., Aravinthan, A., Baik, K. S., Choi, S. Y., Kim, J.-I, Son, Y.-J., Kim, J.-H, Cho, J. Y., Tabetri ${ }^{\mathrm{TM}}$ (Tabebuia avellanedae Ethanol Extract) Ameliorates Atopic Dermatitis Symptoms in Mice, Mediators of Inflammation $2018 \quad$ (2018) 9079527.

https://doi.org/10.1155/2018/9079527.

[18] Suo, M., Isao, H., Kato, H., Takano, F. Ohta, T., Antiinflammatory constituents from Tabebuia avellanedae, $\begin{array}{lllll}\text { Fitoterapia } & 83 & \text { (8) } & \text { (2012) } & \text { 1484-1488. }\end{array}$ https://doi.org/10.1016/j.fitote.2012.08.014.

[19] Coelho, J. M., Antoniolli, A. B., Silva, D. N., Carvalho, T. M. M. B., Pontes, E. R. J. C., Odashiro, A. N., O efeito da sulfadiazina de prata, extrato de ipê-roxo e extrato de barbatimão na cicatrização de feridas cutâneas em ratos, Revista do Colégio Brasileiro de Cirurgiões 37 (1) (2010) 045-051. 69912010000100010.

[20] Sampaio, T. P. D., Cartaxo-Furtado, N. A. O., Medeiros, A. C. D., Alves, H. S., Rosalen, P. L., Pereira, J. V., Antimicrobial Potential of Plant Extracts and Chemical Fractions of Sideroxylon obtusifolium (Roem. \& Schult.) T.D. Penn on Oral Microorganisms, The Journal of Contemporary Dental Practice 18 (5) (2017) 392-398. https://www.thejcdp.com/doi/JCDP/pdf/10.5005/jp-journals10024-2053.

[21] Costa, E. V., Menezes, L. R. A., Rocha, S. L. A., Baliza, I. R. S., Dias, R. B., Rocha, C. A. G., Soares, M. B. P., Bezerra, D. P., Antitumor Properties of the Leaf Essential Oil of Zornia brasiliensis, Planta Medica 81 (7) (2015) 563567. https://doi.org/10.1055/s-0035-1545842.

[22] Silva, T. C, Silva, J. M., Ramos, M. A., What Factors Guide the Selection of Medicinal Plants in a Local Pharmacopoeia? A Case Study in a Rural Community from a Historically Transformed Atlantic Forest Landscape, Evidence-Based Complementary and Alternative Medicine $2018 \quad$ (2018) 2519212. https://doi.org/10.1155/2018/2519212.

[23] Silva, A. G. M., Silva, M. W. F., Bezerra, G. B., Ramos, C. S., The first report of chemical and biological study of essential oil from Begonia reniformis leaf (Begoniaceae), Eclética Química Journal 42 (1) (2017) 6064. https://doi.org/10.26850/1678-4618eqj.v42.1.2017.p6064.

[24] Almeida, R. N., Barbosa Filho, J. M., Naik, S. R., Chemistry and pharmacology of an ethanol extract of Bumelia sartorum, Journal of Ethnopharmacology 14 (2-3) (1985) 173-85. https://doi.org/10.1016/03788741(85)90085-6.
[25] Nascimento, Y. M., Abreu, L. S., Lima, R. L., Silva, A. D. S., Costa, V. C. O., Melo, J. I. M., Scotti, M. T., Sobral, M. V., Araujo, S. S., Gomes Filho, M. A., Zornioside, a dihydrochalcone $C$-glycoside, and other compounds from Zornia brasiliensis, Revista Brasileira de Farmacognosia 28 (2) (2018)

192-197.

https://doi.org/10.1016/j.bjp.2018.02.003.

[26] Bhattacharyya, J., Barros, C. B., Triterpenoids of Cnidosculus urens, Phytochemistry 25 (1) (1985) 274-276. https://doi.org/10.1016/S0031-9422(00)94550-3.

[27] Madda, D. R., Lavanya M., Pola, S., Sandeep, B. V., Assessment of biological properties of two south Indian medicinal plants of Bacopa monnieri and Anacardium occidentale, International Journal Bioassays 5 (9) (2016) 4899-4905. https://www.ijbio.com/articles/assessment-ofbiological-properties-of-two-south-indian-medicinal-plantsof-bacopa-monnieri-and-anacardium-occidentale.pdf.

[28] Santos, G. H. F., Silva, E.; B., Silva, B. L., Sena, K. X. F. R., Lima, C. S. A., Influence of gamma radiation on the antimicrobial activity of crude extracts of Anacardium occidentale L., Anacardiaceae, rich in tannins. Revista Brasileira de Farmacognosia 21 (3) (2011) 444-449. https://doi.org/10.1590/S0102-695X2011005000045.

[29] Kannan, V. R., Sumathi, C. S., Balasubramanian, V., Ramesh, N., Elementary Chemical Profiling and Antifungal Properties of Cashew (Anacardium occidentale L.) Nuts, Botany Research International 2 (4) (2009) 253-257.

[30] Paramashivappa, R., Kumar, P. P., Vithayathil, P. J., Rao, A. S., Novel Method for Isolation of Major Phenolic Constituents from Cashew (Anacardium occidentale L.) Nut Shell Liquid, Journal of Agricultural and Food Chemistry 49 (5) (2001) 2548-2551. https://doi.org/10.1021/jf001222j.

[31] Tronco, G. B., Ramos, M. P., Linhas de pobreza no Plano Brasil Sem Miséria: análise crítica e proposta de alternativas para a medição da pobreza conforme metodologia de Sonia Rocha, Revista de Administração Pública 51 (2) (2017) 294-311. https://doi.org/10.1590/00347612162786. 